\title{
Comparative Study on Nutrient Utilization of Cross-Bred and Gir Cows Fed Green Lucerne During Winter Season
}

\author{
Om Prakash Choudhary", R.P. Jat, Subhash Yadav, Sohan Lal Boori and Lekhu Kumar \\ Department of Livestock Production Management, Sri Karan Narendra Agriculture University, Jobner (Raj.) INDIA \\ *Corresponding author: OP Choudhary; E-mail: omprakashchoudhary9365@gmail.com
}

Received: 11 July, 2021

Revised: 28 July, 2021

Accepted: 30 July, 2021

\begin{abstract}
The present investigation was conducted Comparative Study on Nutrient Utilization of Cross-Bred and Gir Cows Feed Green Lucerne During Winter Season. Twenty lactating cows (in which 10 Cross-bred and 10 Gir Cows) were divided into four groups on basis of nearest their body weight and milk yield/day at dairy farm of S.K.N. College of Agriculture, Jobner and subjected to four dietary treatments were formulated. i.e. Green Lucerne $10 \mathrm{~kg}+$ Wheat straw ad-lib. + Concentrate for $\mathrm{T}_{1}$ Crossbred, Green Lucerne $20 \mathrm{~kg}+$ Wheat straw ad-lib. + Concentrate for $\mathrm{T}_{2}$ Crossbred, Green Lucerne $10 \mathrm{~kg}+$ Wheat straw ad-lib. + Concentrate for $\mathrm{T}_{3}$ Gir Cow and Green Lucerne $20 \mathrm{~kg}+$ Wheat straw ad-lib. + Concentrate for $\mathrm{T}_{4}$ Gir Cow and the studied for their nutrient utilization. DMI (kg/animal/day) was significantly $(\mathrm{P}<0.05)$ higher in $\mathrm{T}_{2}(12.77)$ than $\mathrm{T}_{1}(12.18), \mathrm{T}_{4}(11.49)$ and $\mathrm{T}_{3}(11.07)$. Average daily intake of CP, DCP and TDN in kg/100 kg body weight was significantly higher $(\mathrm{P}<0.05)$ in $\mathrm{T}_{2}$ compared to other groups. The nutrient utilization as DM, CP, EE, CF and NFE was significantly $(\mathrm{P}<0.05)$ higher in $\mathrm{T}_{4}$ compared to $\mathrm{T}_{3}, \mathrm{~T}_{2}$ and $\mathrm{T}_{1}$ group.
\end{abstract}

\section{HIGHLIGHTS}

(0 DMI (kg/animal/day) was significantly higher in $\mathrm{T}_{2}$ (12.77) than $\mathrm{T}_{1}(12.18)$ Cross breed and $\mathrm{T}_{4}(11.49)$ than $\mathrm{T}_{3}(11.07)$ in Gir Cow. 0 The nutrient utilization as DM, CP, EE, CF and NFE was significantly $(\mathrm{P}<0.05)$ higher in $\mathrm{T}_{4}$ compared to $\mathrm{T}_{3}, \mathrm{~T}_{2}$ and $\mathrm{T}_{1}$ group.

Keywords: Nutrient utilization, Cross-bred, Gir Cow, Green Lucerne

Livestock in India has a very important role in the agricultural sector and consequently in its rural economy. India has 190.90 million cattle population, which includes 39.73 million cross-bred and 151.17 million Indigenous cattle (Anonymous, 2012). The cattle herds include a variety of pure bred which have 43 breeds of Indigenous cattle in India (NBAGR, 2018). Cattle are an important farm animal which plays a significant role in the economy of the country by providing milk, manure, and draught power with very little input. Gir is a famous milch cattle breed of India. Cattle of this breed are famous for their tolerance to stress conditions and resistant to various tropical diseases. Cross-breeding programmed of dairy cattle has played significant role in attaining India's top position as highest milk producer country of the world.
Nutrition plays vital role in exploiting the genetic potential of dairy animals but the biomass resources are very limited and there is shortage of feed and fodder. The green fodders are good sources of energy, protein, fat, minerals and vitamins. There for, the present study will be taken to assess to optimum level of green Lucerne (Medicago sativa) fodder in ration and the effect of the green fodder on nutrient utilization of cross-bred and Gir cows and to make recommendations for better performance of dairy cows.

How to cite this article: Choudhary, O.P., Jat, R.P., Yadav, S., Boori, S.L. and Kumar, L. (2021). Comparative Study on Nutrient Utilization of Cross-Bred and Gir Cows Fed Green Lucerne During Winter Season. J. Anim. Res., 11(04): 681-685.

Source of Support: None; Conflict of Interest: None 


\section{MATERIALS AND METHODS}

The present investigation was conducted 2018-2019 at the Dairy farm, S.K.N. college of Agriculture, Jobner District Jaipur, (Rajasthan, India) for 90 days to assess the effect of green lucerne (Medicago sativa) fodder on nutrient utilization of Cross-bred and Gir Cows. 10 Crossbred (Tharparkar/Sahiwal $\times$ Holstein Friesian) and 10 Gir lactating cows were selected for the experiment. They were randomly divided into four groups of five in each group on the basis of nearest in their body weight and milk yield and four dietary treatments were formulated.

Table 1: Feeding schedule of Cross-bred and Gir cows

\begin{tabular}{ll}
\hline Feed and fodder & Quantity of feed and fodders \\
\hline Green Lucerne & $\begin{array}{l}10 \mathrm{~kg} \text { for } \mathrm{T}_{1} \text { and } \mathrm{T}_{3} \text { group and } 20 \mathrm{~kg} \text { for } \mathrm{T}_{2} \\
\text { and } \mathrm{T}_{4} \text { group. }\end{array}$ \\
Wheat straw & $\begin{array}{l}\text { fed ad-lib. } \\
\text { Concentrate mixture }\end{array}$ \\
$\begin{array}{l}2.0 \mathrm{~kg} \text { for maintenance ration } / \text { cow and } @ \\
1 \mathrm{~kg} / 2.5 \text { litre milk yield for production } \\
\text { ratio }\end{array}$ \\
\hline
\end{tabular}

The feed intake data comprising the intake of roughage and concentrate of each animal in all treatments was recorded on two consecutive days at fortnightly interval. A representative sample green Lucerne, dry fodder (wheat straw) and concentrate mixture offered to the animals and refusal left in each treatment was taken fortnightly for estimating the dry matter and crude protein contents. A digestibility trial on all Cross-bred and Gir cows was conducted for 6 days collection period of the end of experiment and feed intake, total dung voided was recorded daily throughout the experiment. The intake of CP, DCP and TDN were also calculated. Crude protein was estimated by Automatic Nitrogen/ Protein estimation system and ether extract analyzed with the help of Automatic Soxhlet's apparatus, crude fibre was analyzed with the help of Automatic PC Competable fiber estimation system.

Calculation of Nitrogen-Free Extract (NFE)

$$
\text { NFE }(\%)=100-(\mathrm{CP} \%+\mathrm{CF} \%+\mathrm{EE} \%+\text { Total ash })
$$

Where, $\mathrm{CP}=$ Crude protein

$$
\begin{aligned}
& \mathrm{CF}=\text { Crude fibre } \\
& \mathrm{EE}=\text { Ether extract. }
\end{aligned}
$$

\section{Total Digestible Nutrients (TDN)}

A term used in animal feeding that designates the sum of all the digestible organic nutrients. (Digestible fat is multiplied by 2.25 because of its higher energy content). The TDN is calculated by the following formula:-

$$
\mathrm{TDN}=\mathrm{DCP}+\mathrm{DCF}+\mathrm{DNFE}+\mathrm{DEE} \times 2.25
$$

Where,

$$
\begin{aligned}
& \text { TDN }=\text { Total digestible nutrients }(\mathrm{kg} .) \\
& \mathrm{DCP}=\text { Digestible crude protein } \\
& \mathrm{DCF}=\text { Digestible crude fibre } \\
& \mathrm{DNFE}=\text { Digestible nitrogen free extract } \\
& \mathrm{DEE}=\text { Digestible ether extract }
\end{aligned}
$$

Table 2: Chemical composition (\% DM basis) of feed and fodder

\begin{tabular}{lllllll}
\hline Feed ingredients DM & CP & EE & CF & NFE & ASH \\
\hline Green Lucerne & 16.5 & 17.2 & 02.1 & 32.4 & 37.1 & 11.2 \\
Wheat Straw & 91.5 & 3.55 & 1.82 & 36.58 & 47.55 & 10.55 \\
Concentrate mix. & 90.5 & 19.7 & 03.8 & 10.2 & 56.3 & 10.0 \\
\hline
\end{tabular}

\section{STATISTICAL ANALYSIS}

The experiment data were statistically analyzed using standard statistical methods (Snedecor and Cochran, 1994). The experiment planned with subjected to analysis of variance (ANOVA) for a (2X2) factorial randomized block design (FRBD) and the means were tested by least significance difference.

\section{RESULTS AND DISCUSSION}

\section{Dry matter intake}

The average daily total dry matter intake (TDMI) in $\mathrm{T}_{1}$, $\mathrm{T}_{2}, \mathrm{~T}_{3}$ and $\mathrm{T}_{4}$ groups was $12.18+0.044,12.77+0.036$, $11.07+0.030$ and $11.49+0.053 \mathrm{~kg} / \mathrm{cow}$, respectively DMI per $100 \mathrm{~kg}$ body weight basis was significantly higher in $20 \mathrm{~kg}$ lucerne fed group compare to $10 \mathrm{~kg}$ lucerne fed group in cross-bred and similar trend was obtained in Gir cows. Overall DMI/100 kg body weight was higher in $\mathrm{T}_{2}$ $(2.95+0.013)$ and $\mathrm{T} 1(2.82+0.012)$ cross-bred compare 
to $\mathrm{T}_{4}(2.68+0.021)$ and $\mathrm{T}_{3}(2.58+0.022)$ Gir cows. This indicates that increasing the amount of green lucerne in diet increase the amount of dry matter intake also. Average daily dry matter intake $(\mathrm{kg})$ of per animal are given in Table 3. Similar values of dry matter intake per $100 \mathrm{~kg}$ body weight was reported by Naik et al. (2012).

Table 3: Average daily dry matter intake $(\mathrm{kg})$ of per animal under different treatment

\begin{tabular}{lllll}
\hline \multirow{2}{*}{ Parameters } & \multicolumn{3}{c}{ Cross Bred } & \multicolumn{2}{c}{ Gir cow } \\
\cline { 2 - 5 } & $\mathbf{T}_{\mathbf{1}}$ & $\mathbf{T}_{\mathbf{2}}$ & $\mathbf{T}_{\mathbf{3}}$ & $\mathbf{T}_{\mathbf{4}}$ \\
\hline Lucerne & $1.65^{\mathrm{cd}} \pm$ & $2.34^{\mathrm{a}} \pm$ & $1.65^{\mathrm{d}} \pm$ & $2.22^{\mathrm{b}} \pm$ \\
& 0.000 & 0.026 & 0.000 & 0.014 \\
Wheat straw & $6.25^{\mathrm{a}} \pm$ & $6.10^{\mathrm{b}} \pm$ & $5.37^{\mathrm{c}} \pm$ & $5.17^{\mathrm{d}} \pm$ \\
& 0.009 & 0.019 & 0.014 & 0.015 \\
Concentrate & $4.28^{\mathrm{b}} \pm$ & $4.33^{\mathrm{a}} \pm$ & $4.05^{\mathrm{d}} \pm$ & $4.10^{\mathrm{c}} \pm$ \\
& 0.072 & 0.050 & 0.053 & 0.078 \\
Total DMI & $12.18^{\mathrm{b}} \pm$ & $12.77^{\mathrm{a}} \pm$ & $11.07^{\mathrm{d}} \pm$ & $11.49^{\mathrm{c}} \pm$ \\
& 0.044 & 0.036 & 0.030 & 0.053 \\
DMI kg/100 kg BW & $2.82^{\mathrm{b}} \pm$ & $2.95^{\mathrm{a}} \pm$ & $2.58^{\mathrm{d}} \pm$ & $2.68^{\mathrm{c}} \pm$ \\
& 0.012 & 0.013 & 0.022 & 0.021 \\
\hline
\end{tabular}

Means having different superscripts differ significantly $(\mathrm{P}<0.05)$.

\section{Total water intake}

The average daily total water intake (litre) in $\mathrm{T}_{1}, \mathrm{~T}_{2}, \mathrm{~T}_{3}$ and $\mathrm{T}_{4}$ groups was $46.31 \pm 0.084,46.49 \pm 0.070,40.47 \pm 0.083$ and $42.06 \pm 0.085$ respectively. The total water intake was higher in T2 than T1, T4 and T3. the differences between treatments were significant. The average daily voluntary water intake (litre) in $\mathrm{T}_{1}, \mathrm{~T}_{2}, \mathrm{~T}_{3}$ and $\mathrm{T}_{4}$ groups was $36.93 \pm 0.084,33.63 \pm 0.070,31.20 \pm 0.083$ and $29.92 \pm 0.085$ respectively.

\section{Nutrient intake}

Average daily intake of crude protein, DCP and TDN in $(\mathrm{kg})$ in different treatment groups were presented in table 4. The daily $C P$ intake in $T_{1}, T_{2}, T_{3}$ and $T_{4}$ group cows was $1.349 \pm 0.29,1.472 \pm 0.27,1.272 \pm 0.29$ and $1.373 \pm 0.27$ g, respectively. The CP intake was significantly higher $(\mathrm{P}<0.05)$ in $\mathrm{T}_{2}$ than $\mathrm{T}_{4}, \mathrm{~T}_{1}$ and $\mathrm{T}_{3}$. The average daily DCP intake in $\mathrm{T}_{1}, \mathrm{~T}_{2}, \mathrm{~T}_{3}$ and $\mathrm{T}_{4}$ groups was $0.843 \pm 0.073,0.932 \pm$ $0.020,0.805 \pm 0.080$ and $0.880 \pm 0.043 \mathrm{~kg}$, respectively. The DCP intake was significantly higher $(\mathrm{P}<0.05)$ in $\mathrm{T}_{2}$ than $\mathrm{T}_{4}, \mathrm{~T}_{3}$ and $\mathrm{T}_{1}$. Overall CP and DCP intake per $100 \mathrm{~kg}$ body weight was obtained higher in $20 \mathrm{~kg}$ green lucerne fed group $\mathrm{T}_{2}$ (cross-bred) compared to $\mathrm{T}_{4}$ (Gir cows) and similar trend was observed in $10 \mathrm{~kg}$ green lucerne fed group $\mathrm{T}_{1}$ (cross-bred) compared to group $\mathrm{T}_{3}$ (Gir cows). The results are in agreement with the findings of Singh et al. (2014).

Table 4: Average daily intake of crude protein, DCP and TDN in $(\mathrm{kg})$ in cows under different treatment

\begin{tabular}{lllll}
\hline \multirow{2}{*}{ Parameters } & \multicolumn{2}{c}{ Cross Bred } & \multicolumn{2}{c}{ Gir cow } \\
\cline { 2 - 5 } & $\mathbf{T}_{1}$ & $\mathbf{T}_{2}$ & $\mathbf{T}_{3}$ & $\mathbf{T}_{4}$ \\
\hline Crude protein intake & $1.349^{\mathrm{c}} \pm$ & $1.472^{\mathrm{a}} \pm$ & $1.272^{\mathrm{d}} \pm$ & $1.373 \mathrm{~b}^{\mathrm{c}} \pm$ \\
& 0.29 & 0.27 & 0.29 & 0.27 \\
CPI/100 kg BW & $0.312^{\mathrm{c}} \pm$ & $0.340^{\mathrm{a}} \pm$ & $0.297^{\mathrm{d}} \pm$ & $0.320 \mathrm{~b}^{\mathrm{c}} \pm$ \\
& 0.004 & 0.003 & 0.006 & 0.005 \\
DCP intake & $0.843^{\mathrm{c}} \pm$ & $0.932^{\mathrm{a}} \pm$ & $0.805^{\mathrm{d}} \pm$ & $0.880^{\mathrm{b}} \pm$ \\
& 0.073 & 0.020 & 0.080 & 0.043 \\
DCP intake/ 100 kg & $0.195^{\mathrm{cd}} \pm$ & $0.215^{\mathrm{a}} \pm$ & $0.188^{\mathrm{d}} \pm$ & $0.205 \mathrm{bc} \pm$ \\
BW & 0.008 & 0.007 & 0.008 & 0.007 \\
Daily TDN intake & $7.15^{\mathrm{b}} \pm$ & $7.55^{\mathrm{a}} \pm$ & $6.47^{\mathrm{d}} \pm$ & $6.77^{\mathrm{c}} \pm$ \\
& 0.011 & 0.019 & 0.014 & 0.015 \\
TDN intake /100 & $1.65^{\mathrm{b}} \pm$ & $1.74^{\mathrm{a}} \pm$ & $1.51^{\mathrm{d}} \pm$ & $1.58^{\mathrm{c}} \pm$ \\
kg BW & 0.13 & 0.11 & 0.19 & 0.15 \\
\hline
\end{tabular}

Means having different superscripts differ significantly $(\mathrm{P}<0.05)$.

The daily consumption of TDN by cows was $7.15 \pm 0.011$, $7.55 \pm 0.19,6.47 \pm 0.014$ and $6.77 \pm 0.015 \mathrm{~kg}$ in $\mathrm{T}_{1}, \mathrm{~T}_{2}, \mathrm{~T}_{3}$ and $\mathrm{T}_{4}$ respectively. The green lucerne had significant $(\mathrm{P}<0.05)$ influence on TDN intake by cows. The average daily TDN intake was higher $(\mathrm{P}<0.05)$ in $\mathrm{T}_{2}$ than $\mathrm{T}_{1}, \mathrm{~T}_{3}$ and $\mathrm{T}_{4}$. Overall TDN intake $/ 100 \mathrm{~kg}$ body weight was obtained higher in $\mathrm{T}_{2}$ (cross-bred) compared to $\mathrm{T}_{4}$ (Gir cows) and similar trend was observed in $\mathrm{T}_{1}$ (cross-bred) compared to $\mathrm{T}_{3}$ (Gir cows). The results of the present investigation are in line with Mahmoud and Ebeid (2014).

\section{Digestibility Co-efficient of feed nutrients}

The average digestibility co-efficient of various nutrients in different experimental groups are presented in Table 5 , which indicated that the digestibility coefficient of all nutrients

\section{Dry matter}

The average digestibility of DM in $\mathrm{T}_{1}, \mathrm{~T}_{2}, \mathrm{~T}_{3}$ and $\mathrm{T}_{4}$ was $60.99 \pm 0.142,61.09 \pm 0.200,62.05 \pm 0.196$ and $62.67 \pm 0.214$ 
per cent, respectively. The digestibility co-efficient of DM was higher $(\mathrm{P}<0.05)$ in $\mathrm{T}_{4}$ than $\mathrm{T}_{3}, \mathrm{~T}_{2}$ and $\mathrm{T}_{1}$ groups. $\mathrm{T}_{2}$ contain higher digestibility co-efficient of DM compared to $T_{1}$ in cross-bred and similar trend was observed in $T_{4}$ compared to $\mathrm{T}_{3}$ in Gir cows. Overall digestibility coefficient of DM was obtained higher in $20 \mathrm{~kg}$ green lucerne fed group $\mathrm{T}_{4}$ (Gir cows) compared to group $\mathrm{T}_{2}$ (cross-bred) and similar trend was reported in $10 \mathrm{~kg}$ green lucerne fed group $\mathrm{T}_{3}$ (Gir cows) compared to group $\mathrm{T}_{1}$ (cross-bred).

\section{Crude protein}

The digestibility of $\mathrm{CP}$ in $\mathrm{T}_{1}, \mathrm{~T}_{2}, \mathrm{~T}_{3}$ and $\mathrm{T}_{4}$ was $62.49 \pm 0.294$, $63.31 \pm 0.202,63.28 \pm 0.229$ and $64.09 \pm 0.258$ per cent, respectively. Which was higher $(\mathrm{P}<0.05)$ in $\mathrm{T}_{4}$ than $\mathrm{T}_{2}, \mathrm{~T}_{3}$ and $T_{1}$ groups. $T_{2}$ contain higher digestibility co-efficient of CP compared to $T_{1}$ in (cross-bred) and similar trend was observed in $T_{4}$ compared to $T_{3}$ (Gir cows). Overall digestibility co-efficient of $\mathrm{CP}$ was higher in $20 \mathrm{~kg}$ green lucerne fed group $\mathrm{T}_{4}$ (Gir cows) compared to group $\mathrm{T}_{2}$ (cross-bred) and similar trend was observed in $10 \mathrm{~kg}$ green lucerne fed group $\mathrm{T}_{3}$ (Gir cows) compared to group $\mathrm{T}_{1}$ (cross-bred). Similar findings were reported by Yadav and Chaudhary (2010).

\section{Ether extract}

The digestibility of EE in $\mathrm{T}_{1}, \mathrm{~T}_{2}, \mathrm{~T}_{3}$ and $\mathrm{T}_{4}$ was $66.55 \pm 0.226$, $68.0 \pm 0.150,66.78 \pm 0.176$ and $68.68 \pm 0.149$ per cent, respectively. $T_{2}$ contain higher digestibility co-efficient of EE compared to $T_{1}$ in (cross-bred) and similar trend was observed in $\mathrm{T}_{4}$ compared to $\mathrm{T}_{3}$ in (Gir cows). Overall digestibility co-efficient of $\mathrm{EE}$ was obtained higher in 20 $\mathrm{kg}$ green lucerne fed group $\mathrm{T}_{4}$ (Gir cows) compared to group $\mathrm{T}_{2}$ (cross-bred) and similar trend was observed in $10 \mathrm{~kg}$ green lucerne fed group $\mathrm{T}_{3}$ (Gir cows) compared to group $\mathrm{T}_{1}$ (cross-bred).

\section{Crude fiber}

The digestibility of $\mathrm{CF}$ in $\mathrm{T}_{1}, \mathrm{~T}_{2}, \mathrm{~T}_{3}$ and $\mathrm{T}_{4}$ was $62.85 \pm 0.116,63.26 \pm 0.146,62.88 \pm 0.262$ and $63.38 \pm 0.213$ per cent, respectively. The digestibility co-efficient of CF was higher $(\mathrm{P}<0.05)$ in $\mathrm{T}_{4}$ as compared to $\mathrm{T}_{1}, \mathrm{~T}_{2}$ and $\mathrm{T}_{3}$. $\mathrm{T}_{2}$ contain higher digestibility co-efficient of $\mathrm{CF}$ compared to $\mathrm{T}_{1}$ in (cross-bred) and also similar trend was observed in $\mathrm{T}_{4}$ compared to $\mathrm{T}_{3}$ in (Gir cows). Overall digestibility co- efficient of CF was obtained higher in $20 \mathrm{~kg}$ green lucerne fed group $\mathrm{T}_{4}$ (Gir cows) compared to $\mathrm{T}_{2}$ (cross-bred) and similar trend was observed in $10 \mathrm{~kg}$ green lucerne fed group $\mathrm{T}_{3}$ (Gir cows) compared to $\mathrm{T}_{1}$ (cross-bred).

\section{Nitrogen free extract}

The digestibility of NFE in $\mathrm{T}_{1}, \mathrm{~T}_{2}, \mathrm{~T}_{3}$ and $\mathrm{T}_{4}$ was $63.28 \pm 0.137,63.70 \pm 0.179,62.50 \pm 0.101$ and $62.89 \pm 0.124$ per cent, respectively. The digestibility of nitrogen free extract was higher $(\mathrm{P}<0.05)$ in $\mathrm{T}_{2}$ than $\mathrm{T}_{1}, \mathrm{~T}_{4}$ and $\mathrm{T}_{3}$ group animals. $T_{2}$ contain higher digestibility co-efficient of NFE compared to $T_{1}$ in (cross-bred) and similar trend was observed in $\mathrm{T}_{4}$ compared to $\mathrm{T}_{3}$ in (Gir cows). Overall digestibility co-efficient of NFE was higher in $20 \mathrm{~kg}$ green lucerne fed group $T_{2}$ (cross-bred) compared to $T_{4}$ (Gir cows) and similar trend was observed in $10 \mathrm{~kg}$ green lucerne fed group $\mathrm{T}_{1}$ (cross-bred) compared to $\mathrm{T}_{3}$ (Gir cows).

Table 5: Average digestibility coefficient of nutrient under different treatment.

\begin{tabular}{lllll}
\hline \multirow{2}{*}{ Nutrients } & \multicolumn{2}{c}{ Cross Bred } & \multicolumn{2}{c}{ Gir cow } \\
\cline { 2 - 5 } & $\mathbf{T}_{1}$ & $\mathbf{T}_{2}$ & $\mathbf{T}_{3}$ & $\mathbf{T}_{4}$ \\
\hline $\mathrm{DM}$ & $60.99^{\mathrm{cd}} \pm$ & $61.09^{\mathrm{d}} \pm$ & $62.05^{\mathrm{b}} \pm$ & $62.67^{\mathrm{a}} \pm$ \\
& 0.142 & 0.200 & 0.196 & 0.214 \\
$\mathrm{CP}$ & $62.49^{\mathrm{d}} \pm$ & $63.31^{\mathrm{bc}} \pm$ & $63.28^{\mathrm{c}} \pm$ & $64.09^{\mathrm{a}} \pm$ \\
& 0.294 & 0.202 & 0.229 & 0.258 \\
$\mathrm{EE}$ & $66.55^{\mathrm{d}} \pm$ & $68.0^{\mathrm{b}} \pm$ & $66.78^{\mathrm{cd}} \pm$ & $68.68^{\mathrm{a}} \pm$ \\
& 0.226 & 0.150 & 0.176 & 0.149 \\
$\mathrm{CF}$ & $62.85^{\mathrm{d}} \pm$ & $63.26^{\mathrm{b}} \pm$ & $62.88^{\mathrm{cd}} \pm$ & $63.38^{\mathrm{a}} \pm$ \\
& 0.116 & 0.146 & 0.262 & 0.213 \\
NFE & $63.28^{\mathrm{b}} \pm$ & $63.70^{\mathrm{a}} \pm$ & $62.50^{\mathrm{d}} \pm$ & $62.89^{\mathrm{cd}} \pm$ \\
& 0.137 & 0.179 & 0.101 & 0.124 \\
\hline
\end{tabular}

Means having different superscripts differ significantly $(\mathrm{P}<0.05)$.

\section{Apparent digestibility}

Apparent digestibility for sake of brevity will hereafter be called digestibility. Apparent digestibility of DM, CP, EE, CF and NFE were significantly $(\mathrm{P}<0.05)$ higher in $\mathrm{T}_{2}$ as compared to $T_{1}$ in (cross-bred) and similar trend was observed in $\mathrm{T}_{4}$ compared to $\mathrm{T}_{3}$ in (Gir cows) due to higher utilization of nutrients. Apparent digestibility of DM, $\mathrm{CP}, \mathrm{EE}, \mathrm{CF}$ and NFE were significantly $(\mathrm{P}<0.05)$ higher in Gir cows compared to Cross-bred. The results are in agreement with the findings of Pachauri and Singh (1990), 
Sarwar et al. (2005), Mahanta and Karnani (2010), Singh et al. (2011) and Mahmoud and Ebeid (2014).

\section{CONCLUSION}

On the basis of present investigation, it may be concluded that the feeding level of $20 \mathrm{~kg}$ green lucerne group was significantly $(\mathrm{P}<0.05)$ higher in nutrient utilization as compared to $10 \mathrm{~kg}$ green lucerne fed group. And average nutrient utilization was higher in Gir cow group $\left(\mathrm{T}_{3}\right.$ and $\mathrm{T}_{4}$ ) compare to Cross-bred group $\left(\mathrm{T}_{1}\right.$ and $\left.\mathrm{T}_{2}\right)$. It is also showed that the better performance as well as increased palatability and utility of wheat straw in same group of Cross-bred and Gir cows.

\section{REFERENCES}

Anonymous 2012. Department of animal husbandry, dairying and fisheries, Ministry of Agriculture, Govt. of India.

Mahanta, S.K. and Karnani, L.K. 2010. Performance of growing crossbred female calves fed different ratios of JHB-146 variety of green berseem and straw. Indian J. Anim. Sci., 80(1): 53- 56.

Mahmoud, A.E.M. and Ebeid, H.M. 2014. Effect of green forage type on productive performance and milk composition of lactating Egyptian buffalo. Asian J. Anim. Vet. Adv., 9(1): 2736.
Naik, P.K., Swain, B.K., Chakurkar, E.B. and Singh, N.P. 2012. Performance of dairy cows on green fodder maize based ration in coastal hot and humid climate. Anim. Nutr. Feed Techno., 12(2): 265-270.

NBAGR, 2018. National Bureau of Animal Genetic Resources, Karnal.

Singh, B., Chaudhary, J.L. and Yadav, C.M. 2011. Effect of feeding different levels of cereal green fodder on the performance of crossbred cows. Anim. Nutr. Feed Techno., 11(2): 285- 292.

Singh, S., Kushwaha, B.P., Maity, S.B., Singh, K.K. and Das, N. 2014. Effect of nutrients level and source on feed intake, nutrients digestibility, rumen profile, blood metabolites and growth in Bhadawari buffalo female calves. Indian J. Anim. Sci., 84(4): 442-446.

Snedecor, G.W. and Cochran, W.G. 1994. Statistical methods. 8th Edn. Lowa state University Press, Ames, lowa.

Yadav, C. M., and Chaudhary, J.L. 2010. Effect of feeding protected protein on nutrient utilization, milk yield and milk composition of lactating crossbred cows. Indian J. Anim. Nut., 27(4): 394-399. 
